\author{
St ud i P hilos o p h i c a \\ Wrat i s l a vi e n s a \\ vol. XVI, fasc. 1 (2021)
}

https://doi.org/10.19195/1895-8001.16.1.11

\author{
MAREK BEASZCZYK \\ ORCID: 0000-0001-5518-0115 \\ Uniwersytet Mikołaja Kopernika w Toruniu
}

\title{
Egzystencjalizm jako filozofia, literatura i styl życia
}

Dawid Szkoła, Pomiędzy filozofia a stylem życia. Egzystencjalizm w polskiej prozie pokolenia '56, Oficyna Wydawnicza ATUT, Wrocław 2019, ss. 298.

Książka Dawida Szkoły zatytułowana Pomiędzy filozofia a stylem życia. Egzystencjalizm $w$ polskiej prozie pokolenia '56, która ukazała się nakładem Oficyny Wydawniczej ATUT w 2019 roku$^{1}$, stanowi ważne przedsięwzięcie naukowe. Nie tylko bowiem omawia specyfikę egzystencjalizmu jako kierunku filozoficznego, intelektualnej mody i stylu życia, ale i w interesujący sposób przybliża najważniejsze wątki tego typu myślenia w utworach takich polskich pisarzy, jak Stanisław Czycz, Ireneusz Iredyński, Stanisław Stanuch i Eugeniusz Kabatc. Monografia zasługuje na uwagę także dlatego, że celnie ukazuje związek filozofii i literatury w kontekście refleksji człowieka nad własnym byciem.

Cel swojej rozprawy Szkoła formułuje następująco: „chcę się skupić na wieloznaczności terminu egzystencjalizm oraz zbadać niespokojne granice literatury i filozofii, ich wzajemne przenikanie się i oddziaływanie. Następnie zaś wykażę, że egzystencjalizm nie był tylko zjawiskiem zachodnioeuropejskim, ale zaistniał $\mathrm{w}$ literaturze na polskim gruncie Pokolenia '56"2. Jego praca doskonale więc wpisuje się w dotychczasowy nurt badań nad egzystencjalizmem w literaturze polskiej, którego głównymi reprezentantami są między innymi Michał Januszkiewicz ${ }^{3}$,

1 D. Szkoła, Pomiędzy filozofia a stylem życia. Egzystencjalizm w polskiej prozie pokolenia '56, Wrocław 2019.

2 Ibidem, s. 14.

${ }^{3}$ M. Januszkiewicz, Tropami egzystencjalizmu w literaturze polskiej XX wieku. O prozie Aleksandra Wata, Stanisława Dygata i Edwarda Stachury, Poznań 1998. 
Waleria Szydłowska ${ }^{4}$, Stefan Morawski ${ }^{5}$ czy Hanna Gosk ${ }^{6}$. Szkoła nie tylko odwołuje się do ich intuicji, lecz nader chętnie korzysta też z rozpoznań takich badaczy egzystencjalizmu, jak choćby Jacek Aleksander Prokopski ${ }^{7}$, Mirosław Żelazny $^{8}$ czy Krzysztof Michalski ${ }^{9}$. Jak sam pisze: „na tych autorów jednak powołuję się w tej pracy najczęściej, uważam, że bez ich tekstów ta praca byłaby o wiele uboższa, a być może w ogóle by nie powstała"10. Mimo widocznego zadłużenia u wymienionych autorów, a niekiedy nawet nie dość krytycznego podążania za obiegowymi interpretacjami egzystencjalizmu, niewątpliwą zaletą jego monografii jest wszakże ukazanie fundamentalnych zagadnień i motywów egzystencjalnych w prozie Czycza, Iredyńskiego, Stanucha i Kabatca. Jak konstatuje Szkoła: „każdy z tej czwórki na swój sposób analizował zagadnienie wrzucenia człowieka w obcy mu świat, wolność i odpowiedzialność jednostki, tragizm i absurd jej istnienia"11.

Praca składa się z pięciu rozdziałów: $O$ czym myślimy, kiedy mówimy o egzystencjalizmie?, Związki, style, konteksty, Stanisław Czycz: całkowita osobność, Pomiędzy wolnościa a nihilizmem w prozie Ireneusza Iredyńskiego oraz Eugeniusza Kabatca i Stanisława Stanucha portrety rozpaczy. Szkoła słusznie zauważa, że egzystencjalizm to nurt ,antysystemowy, często sprzeczny wewnętrznie"12, akcentujaccy problem wolności, samotności, autentyczności, absurdu i tragizmu ludzkiego życia. Nurt ten, w przeciwieństwie do „klasycznych” kierunków filozoficznych (jak na przykład kantyzm, neokantyzm, heglizm czy pozytywizm), w centrum swego zainteresowania stawia bowiem człowieka „z krwi i kości”, a nie abstrakcyjny (zaświatowy), zdepersonalizowany podmiot transcendentalny. Gloryfikuje więc jego indywidualność, jednostkowość, ontyczną wyjątkowość.

Szkoła, charakteryzując specyfikę egzystencjalizmu, omawia antyheglowską filozofię Kierkegaarda, afirmującą absurd i niejednoznaczność religijną myśl Szestowa, „buntowniczą”, antydogmatyczną refleksję Nietzschego, poszukującą drogi do autentycznego sposobu egzystowania filozofię Heideggera i Jaspersa oraz poglądy Sartre'a i Camusa, podkreślających prymat wolności i tragizm ludzkiego życia. To właśnie ci dwaj ostatni, których twórczość obejmuje zarówno dzieła literackie, jak i prace stricte filozoficzne, najbardziej przyczynili się do spopularyzowania egzystencjalizmu, dzięki czemu dość szybko stał się on swoistą modą intelektualną, stylem życia, a nawet fenomenem kulturowym.

Szkoła, nawiązując do rozpoznań Michała Januszkiewicza ${ }^{13}$, celnie omawia fenomen interpretacji egzystencjalnej. Powiada, że owa interpretacja angażuje egzy-

\footnotetext{
${ }^{4}$ W. Szydłowska, Egzystencja-lizm w kontekstach polskich. Szkic o doświadczeniu, myśleniu i pisaniu powojennym, Warszawa 1997.

5 S. Morawski, Watki egzystencjalistyczne w polskiej prozie lat trzydziestych, [w:] Problemy literatury polskiej lat 1890-1939, seria I, H. Kirchner, Z. Żabicki (red.), Wrocław 1972, s. 465-532.

${ }^{6}$ H. Gosk, Wizerunek bohatera. O debiutanckiej prozie polskiej przełomu 1956 roku, Warszawa 1992.

7 J.A. Prokopski, Egzystencja i tragizm. Dialektyka ludzkiej skończoności, Kęty 2007.

8 M. Żelazny, Filozofia i psychologia egzystencjalna, Toruń 2011.

${ }^{9}$ K. Michalski, Heidegger i filozofia współczesna, Warszawa 1978.

10 D. Szkoła, Pomiędzy filozofia a stylem życia, s. 15.

11 Ibidem.

12 Ibidem, s. 7.

13 M. Januszkiewicz, W-koło hermeneutyki literackiej, Warszawa 2007, s. 62; idem, Kim jestem ja, kim jesteś ty? Etyka, tożsamość, rozumienie, Poznań 2012, s. 125-126. Na marginesie: interesujące
} 
stencję samego badacza. Nie jest on bowiem całkowicie „neutralnym” obserwatorem życia, „na chłodno" zdającym sprawę z jego przebiegu. Rozumienie i interpretacja zdają się raczej sposobem ludzkiego bycia. Interpretator nie jest więc jedynie „biernym deszyfratorem tekstu"14, wierzącym w istnienie jedynej słusznej jego wykładni, lecz kimś, kto „chce znaleźć odpowiedź na pytanie o to, jak sam tekst na niego wpływa, jak go kształtuje i do jakich projektów potrafi go zainspirować"15. Interpretacja egzystencjalna, jak nietrudno zauważyć, nie ma tym samym charakteru zamkniętego. Podobnie jest w przypadku wiedzy o człowieku i jego egzystencji: „,nie może być mowy o jednym, prawdziwym odczytaniu tekstu, tak jak nie może być mowy na temat jednego wzoru na człowieka"16. Słowem: interpretacja egzystencjalna jest otwartym procesem, tak jak ludzka egzystencja jest ruchem in statu nascendi.

Egzystencjalizm był nie tylko kierunkiem filozoficznym i prądem literackim, lecz także pewnym stylem życia, nonkonformistyczną modą, akcentującą subiektywizm, indywidualizm czy ,ppotoczny pesymizm"17. Stał się swoistym fenomenem kulturowym ${ }^{18}$, zyskujaccym ogromną popularność tam, gdzie rażąco zachwiana została wiara w człowieka, w dotychczasowe wartości humanistyczne, religijne i moralne. Lata powojenne w Polsce stanowiły więc doskonały grunt dla pojawienia się refleksji egzystencjalistycznej: „młodzi twórcy debiutujący podczas przełomu październikowego wyczuwali podskórnie problemy bliskie egzystencjalistom"19. Wielokrotnie zderzali się bowiem z poczuciem samotności, zagubienia i niezrozumienia, absurdu, chaosu i tragizmu istnienia. Kiedy konfrontowali swe marzenia i pasje z „nieczułym" systemem, rodziło się w nich zarazem pragnienie wolności i autentyczności.

Warto pamiętać, że owa „moda” na egzystencjalizm często niewiele miała wspólnego z pogłębionym namysłem filozoficznym nad jego założeniami. Przeważnie ograniczała się ona do dość wyrywkowego cytowania prac Sartre'a i Camusa, prowadzenia kawiarnianych dyskusji oraz specyficznego zachowania czy stylu ubierania się (czarne swetry, czarne golfy, długie, workowate spódnice). Jak wspomina Agnieszka Osiecka: „ludzie wydzierali sobie Sartre'a, opijali się potwornie mocną herbatą, łazili po nocy na cmentarz i palili papierosy w charakterystyczny sposób — do końca, do poparzenia palców i ust. [...] Chłopcy odkrywali słynny sartre’owski ból istnienia i tarzali się w nim piszczac z rozkoszy"20. Moda na egzystencjalizm wprawdzie zbanalizowała filozofię egzystencjalną, jednak — na poziomie psychologicznym — dała młodym ludziom poczucie przynależności do wspólnoty, potęgując antysystemowe nastroje.

\footnotetext{
intuicje (inspirowane między innymi myślą Martina Heideggera) na temat relacji filozofii i literatury, bycia i rozumienia, egzystencji i interpretacji znaleźć można także w najnowszej książce Januszkiewicza, na którą Szkoła akurat się nie powołuje. Por. M. Januszkiewicz, Być i rozumieć. Rozprawy i szkice z humanistyki hermeneutycznej, Kraków 2017.

14 D. Szkoła, Pomiędzy filozofia a stylem życia, s. 105.

15 Ibidem.

16 Ibidem, s. 278.

17 Ibidem, s. 116.

18 K. Toeplitz, Egzystencjalizm jako zjawisko kulturowe, Gdańsk 1983.

19 D. Szkoła, Pomiędzy filozofia a stylem życia, s. 109.

20 A. Osiecka, Szpetni czterdziestoletni, Warszawa 1987, s. 78.
} 
Najciekawsze fragmenty monografii Szkoły dotyczą interpretacji twórczości Stanisława Czycza, Ireneusza Iredyńskiego, Eugeniusza Kabatca i Stanisława Stanucha. Czycz, zauważa wrocławski uczony, nie tylko pisał o samotności, ale i sam ,pielęgnował swoje poczucie odrębności”'21. Żył raczej na uboczu, autentycznie przeżywając egzystencjalną trwogę. O tym zdają się też traktować jego teksty. Opisuje on bowiem życie jako nieustanne pasmo ludzkich dramatów, cierpień i niedoli. Człowiek, jak widzi go Czycz, skazany jest na ,walkę" z absurdem istnienia, tu i ówdzie spotykanymi niedogodnościami i przeciwnościami losu. Szkoła, jak najbardziej słusznie, ukazuje bohatera Czycza jako doznającego sartre’owskich „mdłości” outsidera (samotnika), nawiązując między innymi do rozpoznań Colina Wilsona ${ }^{22}$ czy Emila Ciorana $^{23}$. Egzystencjalizm Czycza przejawia się więc niezgodą jego bohaterów na uczestniczenie w skonwencjonalizowanym systemie społecznym, utrwalającym jedynie ,pozory sensowności”"24 ludzkiego życia. Tym samym odrzucają oni wszelkie fasady rzeczywistości, wytrwale poszukując subiektywnej prawdy o sobie i świecie.

Twórczość prozatorska Iredyńskiego, niestroniącego od alkoholu awanturnika, przede wszystkim dotyczy zagadnień wolności i nihilizmu. Jego bohaterowie (a właściwie antybohaterowie ${ }^{25}$ ) stale próbują przekraczać społecznie obowiązujące zasady, normy czy konwencje. Są buntownikami, obnażającymi obłudę i pozory szczęśliwego życia. Z tego tė̇ powodu uchodzą za nihilistów, podważających zasadność, sensowność ludzkich działań, dążeń i celów. Szkoła trafnie zauważa, powołując się na konstatacje Fryderyka Nietzschego ${ }^{26}$ i Michała Januszkiewicza ${ }^{27}$, że nihilizm nie oznacza bynajmniej kompletnej negacji czy absolutnej destrukcji wszystkich dotychczasowych wartości, lecz zdaje się być jedynie diagnozą współczesności. Nietzsche nie tyle więc uśmiercił Boga ${ }^{28}$, ile raczej odnalazł Go już martwego u schyłku swojej epoki. Nihilizm jawi się tutaj jako jedno z fundamentalnych doświadczeń egzystencjalnych, a nawet - jako jeden z głównych określników bycia-w-świecie. Człowiek Iredyńskiego, demaskując iluzje rzeczywistości, otwiera nam oczy na własne usytuowanie w świecie; uświadamia konwencjonalność panującej ideologii, moralności czy wszelkich „umów społecznych”. Autor Dnia oszusta, choć sam potocznie nazywany był nihilistą, „odegrał rolę portrecisty swojej epoki i ludzi w niej żyjących”29.

Bohaterowie Kabatca i Stanucha są natomiast samotni, wyobcowani, ,zamknięci w klatce własnego losu"30. Nie szukają ucieczki, nie marzą o buncie przeciwko zakłamanemu systemowi społecznemu. Cechuje ich raczej cicha rezygnacja, beznamiętność, poczucie całkowitej zbędności. Mają świadomość, że świat ich nie potrzebuje,

${ }^{21}$ D. Szkoła, Pomiędzy filozofia a stylem życia, s. 129.

22 C. Wilson, Outsider, tłum. M. Traczewska, Poznań 1992.

23 E. Cioran, Upadek w czas, tłum. I. Kania, Warszawa 2008.

24 D. Szkoła, Pomiędzy filozofia a stylem życia, s. 169.

25 Por. M. Januszkiewicz, W horyzoncie nowoczesności: antybohater jako pojęcie antropologii literatury, „Teksty Drugie” 3 (2010), s. 60-78.

${ }^{26}$ F. Nietzsche, Wola mocy, tłum. K. Drzewiecki, S. Frycz, Kraków 2009.

27 M. Januszkiewicz, Horyzonty nihilizmu. Gombrowicz, Borowski, Różewicz, Poznań 2009.

28 F. Nietzsche, Wiedza radosna, tłum. L. Staff, Kraków 2003, s. 110-111.

29 D. Szkoła, Pomiędzy filozofia a stylem życia, s. 186.

30 Ibidem, s. 231. 
że doskonale obędzie się bez nich, a nawet — że dobre uczynki nie zastapia ani nie zniwelują wszechogarniającego zła. Ciekawi ich tylko ich własna „daremność istnienia”. Jak pisze Szkoła: są „bezsilni w walce z losem, samotni i tak naprawdę już niewiele wymagajacy od życia. Prowadzą egzystencję pełną rozczarowania i alienacji. Niczego nie chcą, na nic nie wyczekują"31. Na każdym kroku odczuwają więc niemoc oraz tragizm własnej egzystencji. Wrocławski uczony dostrzega przy tym analogie między twórczością Kabatca i Stanucha a filozofią egzystencjalną Sartre'a i Camusa.

Przejdźmy do uwag krytycznych. Pewien niedosyt budzi fakt, że Szkoła pomija intuicje Sarah Bakewell, która w pracy Kawiarnia egzystencjalistów. Wolność, bycie $i$ koktajle morelowe podejmuje interesujacce go zagadnienia ${ }^{32}$. Ukazuje bowiem egzystencjalizm nie tylko jako niejednorodny, antysystemowy kierunek filozoficzny, lecz także jako fenomen kulturowy, specyficzną modę i sposób bycia. Wskazuje zarazem, że narodziny współczesnego egzystencjalizmu przypadają na rok 1932, kiedy to Jean-Paul Sartre, Simone de Beauvoir i Raymond Aron, delektujacc się morelowymi koktajlami w barze Bec-de-Gaz w Paryżu, dyskutowali nad nowym stylem filozofowania ${ }^{33}$. Aron opowiadał Sartre'owi o fenomenologii, którą właśnie studiował w Berlinie, a ten tak bardzo się nią zafascynował, że sam postanowił ja zgłębić, czego owocem były jego wczesne rozprawy ${ }^{34}$. Lektura książki Bakewell, jak się zdaje, mogłaby pomóc wrocławskiemu badaczowi wychwycić więcej niuansów związanych z omawianym ruchem myślowym. Warto o tym wspomnieć, tym bardziej że jednym z celów jego dysertacji — jak sam pisze — jest właśnie przedstawienie jego „wieloznaczności”35.

Niedosyt wzbudza również dość pobieżne potraktowanie rozróżnienia na egzystencjalizm teistyczny i egzystencjalizm ateistyczny. Dotyczący tej kwestii fragment, można odnieść wrażenie, jest niejako „doklejony” do zakończenia pierwszego rozdziału publikacji Szkoły, który dodatkowo opatruje go komentarzem, że podział ten „nie ma żadnego znaczenia” oraz że „niewiele wnosi dla samego egzystencjalizmu"36. Autor powołuje się przy tym na stanowisko Mary Warnock, wedle której „niewielkie znaczenie dla teorii egzystencjalnej miało uwzględnienie lub nieuwzględnienie wiary w Boga. W praktyce bowiem wiara w Boga nic człowiekowi nie pomoże"37, ponieważ to on jest jedynym kreatorem własnego losu.

31 Ibidem, s. 232.

32 S. Bakewell, Kawiarnia egzystencjalistów. Wolność, bycie i koktajle morelowe, tłum. A. Paszkowska, Warszawa 2018.

33 M. Błaszczyk, Rozmowy w kawiarni. O fenomenie egzystencjalizmu, „Świat i Słowo” 2 (2019), s. $277-284$.

34 Zob. na przykład J.P. Sartre, Transcendencja Ego. Próba opisu fenomenologicznego, tłum. U. Idziak, Warszawa 2006; idem, Wyobrażenie. Fenomenologiczna psychologia wyobraźni, tłum. P. Beylin, Warszawa 1970. Warto też pamiętać, że Byt i nicość, najważniejsza praca filozoficzna Sartre’a, ma podtytuł (,zarys ontologii fenomenologicznej”), który również świadczy o jego inspiracjach fenomenologią. Por. J.P. Sartre, Byt i nicość. Zarys ontologii fenomenologicznej, tłum. J. Kiełbasa et al., Kraków 2007.

35 D. Szkoła, Pomiędzy filozofia a stylem życia, s. 14.

36 Ibidem, s. 86.

37 M. Warnock, Egzystencjalizm, tłum. M. Michowicz, Warszawa 2006, s. 153. 
Oczywiście, można podzielać to przekonanie. Autor nie jest tu wyjątkiem, podobnie zdaje się bowiem twierdzić choćby William Luijpen ${ }^{38}$, do którego wrocławski uczony w ogóle nie nawiązuje, a który wskazuje na wspólny wszystkim egzystencjalistom „klimat myślenia”39. Niemniej jednak przyjrzenie się zaproponowanemu przez Sartre'a ${ }^{40}$ rozróżnieniu na egzystencjalizm ateistyczny i teistyczny może mieć znaczenie w kontekście ukazania swoistości tego nurtu filozoficznego, a takie właśnie zamierzenie formułuje Szkoła we wstępie do swojej monografii. Nie chcemy przez to powiedzieć, że nie zrealizował on należycie postawionego przed sobą celu, wpadając w pułapkę własnych deklaracji. Chcemy jedynie zwrócić uwagę na trudności, z jakimi muszą się zmierzyć wszyscy badacze egzystencjalizmu, zwłaszcza zaś ci, którzy próbują uczynić z niego filozoficzne tło dla nie-filozoficznych rozważań. Naświetlenie jednego zagadnienia niejednokrotnie bowiem wiąże się z marginalizacją innego, co w konsekwencji prowadzi do pewnych uproszczeń i symplifikacji — w przypadku rozprawy Szkoły za pobieżną można choćby uznać jego interpretację Heideggerowskiego egzystencjału Się czy Jaspersowskiego rozumienia komunikacji.

Praca Szkoły nie jest wolna od warsztatowo-edycyjnych mankamentów (na przykład s. 14 , s. 15 , s. 44 , s. 49 , s. 74 , s. 75 , s. 85 , s. 86 , s. 89 , s. 102 , s. 209 , s. 210 , s. 277 , s. 280 , s. 284). Nie pomniejszają one wszakże jej walorów poznawczych czy propedeutycznych. Książka Pomiędzy filozofia a stylem życia. Egzystencjalizm w polskiej prozie pokolenia ' 56 zajmuje ważne miejsce wśród dotychczasowych opracowań traktujących o problematyce egzystencjalnej w literaturze polskiej. W ciekawy sposób omawia bowiem kluczowe wątki egzystencjalne w prozie Stanisława Czycza, Ireneusza Iredyńskiego, Stanisława Stanucha i Eugeniusza Kabatca. Godna jest więc polecenia wszystkim zainteresowanym zarówno samym egzystencjalizmem, jak i jego filozoficznymi motywami obecnymi w polskiej prozie twórców przełomu październikowego.

\section{Bibliografia}

Bakewell S., Kawiarnia egzystencjalistów. Wolność, bycie i koktajle morelowe, tłum.

A. Paszkowska, Warszawa 2018.

Błaszczyk M., Rozmowy w kawiarni. O fenomenie egzystencjalizmu, „Świat i Słowo” 2 (2019), s. 277-284.

Cioran E., Upadek w czas, tłum. I. Kania, Warszawa 2008.

Gosk H., Wizerunek bohatera. O debiutanckiej prozie polskiej przełomu 1956 roku, Warszawa 1992.

Januszkiewicz M., Być i rozumieć. Rozprawy i szkice z humanistyki hermeneutycznej, Kraków 2017.

Januszkiewicz M., Horyzonty nihilizmu. Gombrowicz, Borowski, Różewicz, Poznań 2009. Januszkiewicz M., Kim jestem ja, kim jesteś ty? Etyka, tożsamość, rozumienie, Poznań 2012.

38 W. Luijpen, Fenomenologia egzystencjalna, tłum. B. Chwedeńczuk, Warszawa 1972.

39 Ibidem, s. 7.

40 J.P. Sartre, Egzystencjalizm jest humanizmem, tłum. J. Krajewski, Warszawa 1998, s. 23. 
Januszkiewicz M., Tropami egzystencjalizmu w literaturze polskiej XX wieku. O prozie Aleksandra Wata, Stanisława Dygata i Edwarda Stachury, Poznań 1998.

Januszkiewicz M., W horyzoncie nowoczesności: antybohater jako pojęcie antropologii literatury, „Teksty Drugie” 3 (2010), s. 60-78.

Januszkiewicz M., W-koło hermeneutyki literackiej, Warszawa 2007.

Luijpen W., Fenomenologia egzystencjalna, tłum. B. Chwedeńczuk, Warszawa 1972.

Michalski K., Heidegger i filozofia wspótczesna, Warszawa 1978.

Morawski S., Watki egzystencjalistyczne w polskiej prozie lat trzydziestych, [w:] Problemy literatury polskiej lat 1890-1939, seria I, H. Kirchner, Z. Żabicki (red.), Wrocław 1972 , s. $465-532$.

Nietzsche F., Wiedza radosna, tłum. L. Staff, Kraków 2003.

Nietzsche F., Wola mocy, tłum. K. Drzewiecki, S. Frycz, Kraków 2009.

Osiecka A., Szpetni czterdziestoletni, Warszawa 1987.

Prokopski J.A., Egzystencja i tragizm. Dialektyka ludzkiej skończoności, Kęty 2007.

Sartre J.P., Byt i nicość. Zarys ontologii fenomenologicznej, tłum. J. Kiełbasa et al., Kraków 2007.

Sartre J.P., Egzystencjalizm jest humanizmem, tłum. J. Krajewski, Warszawa 1998.

Sartre J.P., Transcendencja Ego. Próba opisu fenomenologicznego, tłum. U. Idziak, Warszawa 2006.

Sartre J.P., Wyobrażenie. Fenomenologiczna psychologia wyobraźni, tłum. P. Beylin, Warszawa 1970.

Szkoła D., Pomiędzy filozofia a stylem życia. Egzystencjalizm w polskiej prozie pokolenia '56, Wrocław 2019.

Szydłowska W., Egzystencja-lizm w kontekstach polskich. Szkic o doświadczeniu, myśleniu i pisaniu powojennym, Warszawa 1997.

Toeplitz K., Egzystencjalizm jako zjawisko kulturowe, Gdańsk 1983.

Warnock M., Egzystencjalizm, tłum. M. Michowicz, Warszawa 2006.

Wilson C., Outsider, tłum. M. Traczewska, Poznań 1992.

Żelazny M., Filozofia i psychologia egzystencjalna, Toruń 2011. 